
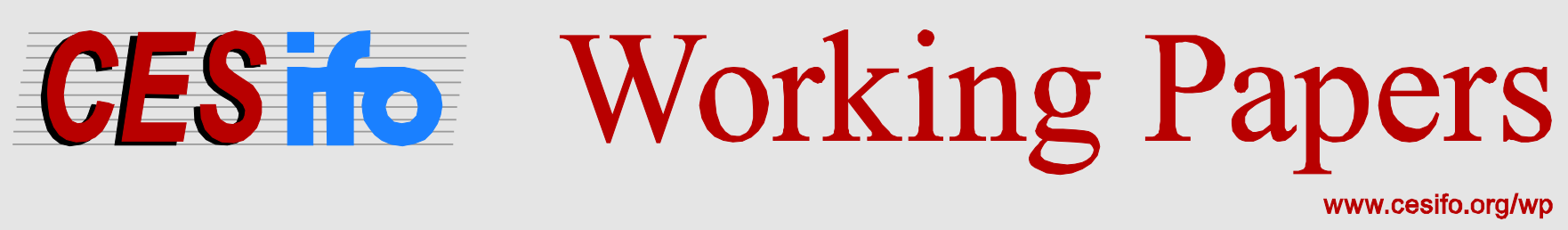

\title{
Anticipated Property Tax Increases and the Timing of Home Sales: Evidence from Administrative Data
}

\author{
William Hoyt \\ Aaron Yelowitz
}

CESIFO WORKING PAPER NO. 6264

CATEgORY 1: PUBlic FinANCE

DECEMBER 2016

An electronic version of the paper may be downloaded

- from the SSRN website:

- from the RePEc website:

- from the CESifo website:

WWW.SSRN.com

www.RePEc.org

www.CESifo-group.org/wp 


\title{
Anticipated Property Tax Increases and the Timing of Home Sales: Evidence from Administrative Data
}

\begin{abstract}
Restrictions imposed on property assessment practices by state legislation such as Proposition 13 in California and Proposition $2 \frac{1}{2}$ in Massachusetts can lead to significant divergences between the assessed and market values of property, particularly for households with long tenures. As properties are assessed at their market value when sold, this can lead to a significant divergence in the property tax payment for a current homeowner and a prospective purchaser of the property. This may lead to "lock-in", decreased mobility, of homeowners reluctant to lose their tax advantage. Here using data on single family dwellings in Lexington, KY (Fayette County) we examine another practice leading to a systematic difference between assessed and market value of properties, the practice of assessing properties in individual neighborhoods on a four-year basis. In times of high housing appreciation, the difference in tax payments for houses last assessed two or three years earlier and their market values, the tax base for a new purchaser, can be significant and lead to a lock-in effect. Using administrative data from the Fayette County PVA we find evidence that housing sales are higher in the year before a neighborhood assessment suggesting that households adjust their mobility to capture the tax advantage associated with limited assessment.
\end{abstract}

JEL-Codes: H200, H710, R300.

Keywords: property taxation, assessment, lock-in.

William Hoyt*

Department of Economics

Gatton College of Business and Economics

University of Kentucky

USA - Lexington, KY 40506

whoyt@uky.edu
Aaron Yelowitz

Department of Economics

Gatton School of Business and Economics

University of Kentucky

USA - Lexington KY, 40506

aaron@uky.edu

*corresponding author

December 2016 


\section{Introduction}

While no tax seems to be popular among Americans, no other tax seems to generate as much animosity as the property tax. It has been suggested that one reason is that the property tax may be more salient than other taxes (Cabral and Hoxby (2015) 2). As Cabral and Hoxby (2015) note, in contrast to income and payroll taxes in which taxpayers have payments withheld and, for the income tax, often receive refunds, almost seventy percent of homeowners directly pay their property taxes. While salience may be one reason for the unpopularity of the property tax, another possible explanation might be concerns among taxpayers about the subjectivity of the tax base - the assessed value of a house. As we discuss more shortly, differences in assessed property values may not only reflect differences in the market value of the house but also the tenure and, in some cases, the political connections of the household 3

This unpopularity undoubtedly explains why property taxes have been subject to so many limitations and restrictions on their use. While the best known of these limitations are those passed between 1978 and 1981, including Proposition 13 in California and Proposition $2 \frac{1}{2}$ in Massachusetts, property tax limitations have been in existence for well over 100 years and are found in almost every state. $!^{4}$

There are three forms of property tax limitations: rate restrictions, revenue (levy) restrictions, and assessment restrictions. While our purpose is not to examine the impacts of these limitations on housing markets, our study, which focuses on the timing of assessment on household mobility, is related to the literature that examines the impacts of assessment restrictions on housing decisions, specifically on household tenure.

Assessment restrictions limit increases in property assessments. Typically and, perhaps most notably in California, the allowable increase in assessments has been well below the market appreciation. In California the allowable annual increase in assessments has been set at two percent. However, when a house is sold, it will be assessed at the market value. This being the case, a household that has remained in the same home for a number of years,

\footnotetext{
${ }^{2}$ Public polling of the American public on the topic of the relative dislike of alternative tax instruments has, apparently, become quite common. Discussions of these polls and surveys can be found in U.S. News and World Report (December 28, 2006), Winchester (NH) Informer (January 11, 2010), and Forbes (June 8, 2011), The New York Times (February 19, 2006), and the Wall Street Journal (February 1, 2006).

${ }^{3}$ That assessments might seem subjective to the taxpayer is perhaps reflected in the increasing numbers of homeowners appealing property tax assessments (Forbes (June 8, 2011)).

${ }^{4}$ While the late 1970's and early 1980's was a period in which a number of states imposed or revised property tax limits, in fact, Missouri first instituted rate limits on property taxes in 1875 . States without any state limits on property taxes include Connecticut, Hawaii, Maine, New Hampshire, South Carolina, Vermont, and Virginia. The District of Columbia has no restrictions on property taxes as well. See Hoyt, Coomes and Biehl (2011) for more detail on the form and timing of state property tax limitations.
} 
particularly during periods of high appreciation, can have an assessment that is significantly both below market value and, therefore, what a new purchaser would be assessed.

These differences in assessed values between a homeowner with a long tenure and a prospective purchaser of the house can lead to significant differences in tax payments. Then limits on assessment increases may lead to "lock-in" - the reluctance of homeowners to sell their current under-assessed properties and purchase other properties assessed at market values. A number of studies, discussed in more detail in the next section, have examined and found evidence of a lock-in effect. In fact, it is not only researchers who recognize these "lock-in" effects - California, as well as several other states, allow for the difference between the assessed and market value to be "portable," that is, the homeowner is allowed to apply this difference to the assessment on their new home.

In this study we, too, examine a lock-in effect. This lock-in is not the result of assessment limitations but the infrequency of assessments. Unlike twenty other states, the Commonwealth of Kentucky does not have statewide restrictions on assessments, that is, a limit on how much assessed property value can increase in a year $5^{5}$ Kentucky statute requires that local property value administrators (PVA) assesses properties at a minimum of every four years at fair cash (market) value. In practice, at least in Lexington, distinct neighborhoods are assessed on a four-year cycle. Then, a household that has lived at a property for three years since the last assessment may, particularly in times of high housing appreciation, have an assessment significantly below what a new purchaser with an assessment based on the market value might face. However, the next year, four years from the previous statute-required, or what we refer to as the neighborhood assessment, the house will be assessed, and, if assessed at market value, the incumbent household will have an assessment comparable to that of a new owner. Thus, like the restrictions on assessments, the gap between neighborhood assessments leads to a difference in tax payments between a current and prospective homeowner.

In this case, then, we believe that the likelihood that a household sells its house depends on the time to another neighborhood assessment. Specifically, we would expect that households are more likely to remain in their home during the years in which they have the lowest tax payments relative to a new homeowner, the year before the assessment. Using administrative data from the Fayette County Property Value Administrator (PVA), we test this prediction, relating the probability of a sale to the time between neighborhood assessments, and find, in fact, that properties are more likely to sell in the year before assessment, that is,

\footnotetext{
${ }^{5}$ At the time of the data used in this study 20 states had statewide limits on assessment increases or limits in selected, highly-populated areas. See Haveman and Sexton (2008) for a listing of state regulations and limits on property tax practices.
} 
immediately before they lose the tax advantage associated with a below-market assessment.

While the literature most-related to our study may be on the impacts of assessment restrictions on "lock-in" in the housing market, our study also has similarities to numerous studies examining how taxes and changes in tax structure affects the timing of economic decisions such including the purchases of financial assets as well as housing. Studies including Biehl and Hoyt (2014) and Cunningham and Engelhardt (2008) find that the differential treatment of capital gains from housing sales for householders under and over fifty-five years of age prior to the Tax Reform Act of 1997 (TRA97) reduced mobility for those under the age of fifty-five. The term "lock-in" also refers to stockholders retaining appreciated stocks in an effort to avoid capital gains taxation. Sinai and Gyourko (2002), and Land and Shackelford (2000) use the changes in capital gains tax rates associated with TRA97 to find capitalization of capital gains taxes in stock prices.

As the impact of the 4-year gap in neighborhood assessments depends, in part, on the extent that the fair cash value determined by assessing a property that has not been sold is consistent with the market and, therefore, fair cash value, of properties that were sold in the last year, we first examine to what extent tenure in a house might influence the fair cash value of that home. To preview our results, we estimate that an additional year of tenure reduces assessed value by 0.19 percent suggesting that the gains to delaying sales until the year of assessment are greater than suggested by market appreciation alone.

In regard to our primary focus, the impact of the four-year gap between neighborhood assessments on mobility, we do find evidence that increased probability of a home sale in the year preceding an automatic neighborhood assessment- the increase in the probability of a home sale in the year before neighborhood assessments is $0.35 \%$ with approximately $6.5 \%$ of the current stock of houses being sold each year in Lexington from 2002 to 2008. Then with annual sales $6.5 \%$ of the housing stock the $0.35 \%$ increase in probability of a sale is a $5.36 \%$ increase. Less clear is whether the increase in sales in the year prior to the four-year neighborhood assessment is due to delays in sales to capture an additional year of the lower tax payment or an earlier sale than otherwise to avoid the higher taxes with the assessment. Both behaviors are possible and it appears that this assessment practice appears to have more of an effect on the short-term timing of home sales and little impact on long-term mobility.

In the next section we discuss related studies, specifically those examining lock-in associated with assessment limitations. Section 3 provides an illustration and numerical examples of what the extent of the difference in tax payments due to the lock-in effect might be. In Section 4 we discuss the data and empirical model. Section 5 presents the empirical methodology, Section 6 reports our findings and Section 7 concludes. 


\section{Literature Review}

There is a large and varied literature on the property tax and, in particular, the impact of property tax limitations. Numerous studies examine the motivation for these regulations on property taxes, that is, what are the political and economic forces that might explain property tax limitations. For example, Anderson (2006) argues that while the notion that property tax limits serve as a constraint on local government expenditures, limits also serve as insurance against unexpected increases in personal property tax liabilities. A related motivation suggested for property tax limitations that coincides with many of the limitations imposed in the 1970's and early 1980's is as a "defense" against inflation-induced increases in property tax liabilities (Bowman (2006): Cornia and Walters (2006)) or Leviathan governments (Cutler, Elmendorf and Zeckhauser (1999). Still other studies focused on the impact that property tax limits had on local revenues and expenditures including Bradbury, Mayer and Case (2001); Lang and Jun (2004). Another strand of the literature on property taxation and property tax limits focuses on the distributional impacts of these limits (Dye, McMillen and Merriman (2006): Hodge et al. (2015):Skidmore, Ballard and Hodge (2010))

While our study is not focusing on property tax limitations on homeowner mobility, it is most related to these studies as it explores an institutional aspect of assessment that "locksin" assessed value for current homeowners. The literature on property taxation and mobility has, for the most part, focused on several "case-study" state-level reforms. Most notably, there are numerous studies on the economic effects of California's Proposition 13. Enacted in 1979, Proposition 13 reduced the property tax rate to one percent of assessed value, and limited increases in assessments to at most two percent per year. However, at time of sale assessments are set to market value, potentially creating a "lock-in" effect, especially for long-tenure owners in rapidly appreciating housing markets. Several other states, including Massachusetts and Florida, have enacted similar limitations on assessments..$^{6}$ A number of states - including California and Florida - have passed laws that allow at least some owners to transfer their property tax savings to another home in the county or state. A second, less common approach in the literature is to examine the effects of property tax exemptions for vulnerable groups (such as homestead exemptions for the elderly) using all 50 states.$^{7}$

The empirical approaches, more often than not, rely on some form of household data and typically examine household behavior immediately before or after a particular legislative change. The reliance on household data - while allowing researchers to include household characteristics that may affect mobility - means researchers often have crude measures of

\footnotetext{
${ }^{6}$ See Ihlanfeldt (2011) and Stansel, Jackson and Finch $(2007)$ for studies on Florida.

${ }^{7}$ See Shan (2010).
} 
mobility and property tax burdens. The focus on the immediate passage of laws also creates potential problems. In some instances, one may not expect to see effects in the short run. For example Nagy (1997), finds little lock-in effect from Proposition 13, but others argue that there was little time to find such impacts because Nagy examines behavior only three years after the law was enacted. In other instances, the short-run effects may be larger than the long-run effects due to pent-up demand. For example, Ferreira (2010) finds large increases in mobility for Californians over the age of 55 using the 1990 Census, soon after several propositions allowed older homeowners to transfer their property tax savings to another home in California. On the other hand, the amendments resulted in much smaller effects in the 2000 Census. Hodge, Sands and Skidmore (2015) examine the impact of taxable value growth caps on mobility using parcel-level data in Detroit, Michigan and finds longer durations of property ownerships for those who have benefited from greater reductions in their effective property tax. Similarly, focusing on Florida's assessment caps, Ihlanfeldt (2011) finds evidence of a lock-in effect for home-owners in single family homes. Stansel, Jackson and Finch (2007) also consider the impact of Florida's assessment caps on housing tenure but find no evidence that the caps, that are portable across Florida, had an impact on tenure. Stohs, Childs and Stevenson (2001) identifies the impact of Proposition 13 on homeowner mobility through comparisons of home sales in selected counties in California with selected counties Illinois and Massachusetts and find fewer housing sales in the California counties. Wasi and White (2005), focusing on the impact of Proposition 13 on tenure. also employ comparison states, Florida and Texas, and a "difference-in-difference" methodology using microdata on households from the 1970 - 2000 Census of Population and Housing. They find that length of tenure in California increased by 0.66 years or 6 percent.

Bradley (2016) utilizes a discontinuity in the tax schedule, a "tax notch," in Michigan law in which properties are only assessed on January $1^{\text {st }}$ regardless of whether the property was sold the preceding year. Not surprisingly, Bradley (2016) finds clear evidence of bunching of sales following the first of the year. Shan (2010) focuses on the impacts of property tax exemptions for the elderly and finds that the mobility of home-owners over the age of 50 is increased by 8 percent for an increase in $\$ 100$ in annual property taxes.

Many lock-in studies clearly recognize the frailties of relying only on the time series variation from the passage of the laws. Although the passage of a law that limits property taxation may certainly affect owner mobility, a host of other factors, including changing employment and housing markets, may also matter. Typically, researchers have examined owners in unaffected markets (e.g., housing markets outside of California in the Proposition 13 context), or owners that are differentially affected by the law (e.g., those with high or low tax savings). Approaches that rely on cross-state control groups often suffer from 
the problem that different property tax systems can be correlated with other underlying characteristics of the state that also affect household mobility $\left.\right|^{8}$ Moreover, these studies have difficulty controlling for differential trends in housing markets over time; these trends could independently affect mobility and may be correlated with the tax savings.9. Approaches that rely on differential tax savings to identify mobility effects often have difficulty in disentangling the causality issues: in appreciating housing markets, longer tenure causes larger property tax savings, while the empirical approach often estimates the impact of property tax savings on mobility which is highly related to tenure.

Relative to existing work, our study offers several innovations. First, our source of tax assessment variation is transparent and clearly exogenous to the household. Second, we rely on tax assessor data, meaning we measure mobility, tax assessments and housing characteristics far more precisely than typical household-based surveys. Third, any fears about differential housing market trends affecting mobility are eliminated by examining mobility within one housing market over time; our exogenous variation occurs on a neighborhood basis. Finally, we examine behavior over a seven-year period from 2002 to 2008, which should greatly reduce concerns about overstating the long-run impact of property taxation due to pent-up demand.

\section{Assessment-Induced Tax Differentials and the Deci- sion to Sell}

Here we illustrate the determinants of the property tax differences that arise between households remaining in their homes and new purchasers when assessment is only done on a multi-year cycle or when a housing sale occurs. Our parameterization of the tax differences gives some indication of their potential magnitudes. As motivation for our empirical work, we then provide a simple characterization of how these tax differences are likely to affect the likelihood of the current household moving.

\subsection{Determinants of Assessment-Induced Tax Differentials}

Assume the current owner either purchased a house for $V^{0}$ or had it last assessed for that amount. Assume that the market value is at time $t$ is $V^{\prime}$, meaning that that a purchase at time $t$ leads to assessment from $V^{0}$ to $V^{\prime}$. At the next neighborhood assessment, scheduled

\footnotetext{
${ }^{8}$ See the discussion in Ferreira (2010).

${ }^{9}$ For example, real housing appreciation in San Francisco has exceed the national average by more than 2 percentage points per year for the years between 1950 and 2000 (Gyourko, Mayer and Sinai (2013)).
} 
for time $T^{A}$, the assessment will be based on the market value at $T^{A}$ regardless of whether the most recent assessment was $V^{0}$ or it was sold at time $t$ for $V^{\prime}$.

Then at time $t$ the difference in discounted property tax payments $\left(\Delta P_{t}\right)$ if the current owner maintains the property rather than selling it for $V^{\prime}$ at time $t$ is

$$
\Delta P_{t}=p \sum_{s=t}^{T^{A}-1} \frac{V^{0}}{(1+r)^{s-t}}-p \sum_{s=t}^{T^{A}-1} \frac{V^{\prime}}{(1+r)^{s-t}}=p\left(V^{0}-V^{\prime}\right) \sum_{s=t}^{T^{A}-1} \frac{1}{(1+r)^{s-t}}
$$

where $p$ is the property tax rate and $r$ is the discount rate. The difference in the present value of tax payments is simply the sum of the difference in (discounted) tax payments until assessment. Alternatively, we can model the market price at time $t$ as being a function of the assessed or market price $\left(V^{o}\right)$ at some time, $T^{0}$, the time since $T^{o}(t)$, and the rate of appreciation (a). Then at time $t$ the property is worth $V(t)=(1+a)^{t-T^{0}} V^{0}$. Substituting this expression of $V(t)$ for $V^{\prime}$ in (1) gives

$$
\Delta P_{t}=p V^{0}\left(1-(1+a)^{t-T^{0}}\right) \sum_{s=t}^{T^{A}-1} \frac{1}{(1+r)^{s-t}}
$$

Of course, as the existing literature on "lock-in" discusses, often property is not assessed at market value either explicitly by statute or implicitly. Instead the maximum increase in appreciation is fixed, usually at a rate significantly below the rate of market appreciation. In this case the difference in future tax payments is even more significant,

$$
\Delta P_{t}=p\left[\sum_{s=t}^{T}\left[\frac{(1+l)}{(1+r)}\right]^{s-t} V^{0}-\sum_{s=t}^{T^{A}-1}\left[\frac{(1+l)}{(1+r)}\right]^{s-t} V^{\prime}\right]
$$

where $l$ is the annualized increase in assessments with $l<a$ and where $T$ is the expected 
life of the property. ${ }^{10}$ Substituting $(1+a)^{t-T^{0}} V^{0}$ for $V^{\prime}$ gives

$$
\Delta P_{t}=p V^{0}\left(1-(1+a)^{t-T^{0}}\right) \sum_{s=t}^{T}\left[\frac{(1+l)}{(1+r)}\right]^{s-t}
$$

As we discuss in Section 6, we estimate the appreciation rate in assessment to be approximately $0.65 \%$ lower than the market appreciation rate.

\subsubsection{Numerical Examples}

In Table 1 we illustrate the impact of these assessment practices on the difference in annual taxes on a property not assessed (not sold) and one that is assessed (sold). Given the initial assessment of the property, the difference in property taxes in subsequent years depends on the tax rate and the rate of appreciation. We illustrate the impacts with three different initial assessed values $(150,000,300,000$, and 600,000), three property tax rates $(0.01,0.015$, and 0.02), and three different appreciation rates (0.03, 0.05, 0.10).

Of course, the rate of appreciation, the longer the time from the last assessment, and the tax rate positively affect the difference in tax payments between selling the property and maintaining ownership. As can be seen in the table, the difference in tax payments can be quite substantial, when appreciation rates, taxes, and property values are high. Thus, for example, with an appreciation rate of ten percent, a two percent tax rate, and an initial value of $\$ 600,000$ after three years there is a difference in the property tax bill of $\$ 3,972$ if the property is sold.

Table 2 provides examples of the difference in the present value of property tax payments for a property not assessed and one that is sold and therefore assessed based on equation (2). In addition to the information required for Table 2, these calculations require specification of a discount rate for which we use 0.04. As our numerical example demonstrates, there is

\footnotetext{
${ }^{10}$ As written, expression (3) has increases in assessment occurring annually at a rate of $l$. As discussed, the assessment process, in the absence of a sale occurs every $T$ years. Then, in fact, rather annual assessment of an increase of $l$, every $\mathrm{T}$ years a property is assessed such that $(1+l)^{T}=1+l^{\prime}$ or at rate every $T$ years of $l^{\prime}=(1+l)^{T}-1$. Less clear is what occurs when a property is sold and the neighborhood is assessed less than $T$ years following the sale. One possibility is that rather having the property assessed at $(1+l)^{T}$ it would assessed at $(1+l)^{T^{*}}$ where $T^{*}$ is the time between the purchase of the property and neighborhood assessment. In this case we might have something like
}

$$
\begin{gathered}
p V^{0}\left[\sum_{s=t}^{T^{A}-1} \frac{1}{(1+r)^{s-t}}+\frac{(1+l)^{T}}{(1+r)^{T^{A}-t}}+\sum_{s=T^{A+1}}^{T^{2 A}} \frac{(1+l)^{T}}{(1+r)^{s-T^{A}}}+\frac{(1+l)^{2 T}}{(1+r)^{2 T^{A}-t}}\right] \\
-p V^{\prime}\left[\sum_{s=t}^{T^{A}-1}\left(\frac{1}{(1+r)^{s-t}}+\frac{(1+l)^{T^{A}}}{(1+r)^{s-T^{A}}}\right)+\sum_{s=T^{A+1}}^{T^{2 A}} \frac{(1+l)^{T^{A}-t}}{(1+r)^{s-T^{A}}}+\frac{(1+l)^{T+\left(T^{A}-t\right)}}{(1+r)^{2 T^{A}}}\right]
\end{gathered}
$$

where $T^{2 A}$ is the period of the second neighborhood assessment. 
not a monotonic relationship between years from assessment and the present value of taxes. In this case, with a discount rate of 0.04 , the greatest difference in property taxes in the two cases is found two years after the property was last assessed. Again, these differences can be quite sizable - in the case of a value assessed at $\$ 600,000$ appreciation at a $10 \%$ rate and taxed at a $2 \%$ rate, two years after assessment, the present value of the difference in taxes is over $\$ 4,943$.

As a final example, we parameterize (4) to demonstrate the impact of limits on appreciation in assessed values. As an example, we consider a property with an initial assessment and

sale value of $\$ 300,000$. We then consider what the distinction in assessed and market value are for a limit of $2 \%$ on assessment increases with different rates of appreciation (2.40\%, $3 \%, 5 \%, 7.5 \%)$ when the property is held for ten years. Based on the difference in appraised and market value and tax rate, the annual tax difference and the present value of the tax difference (with $T=10$ ) after ten years of ownership is then calculated.

As Table 3 shows, with higher appreciation and higher taxes, both the differences in annual and the present value of tax payments become quite large, certainly large enough to affect mobility and tenure and even with the $0.65 \%$ difference between assessed and market appreciation the differences are not trivial.

\subsection{Property Tax Differences and the Decision to Sell}

Given the potential magnitudes of the property tax differences that might exist for a current homeowner and a new owner in the absence of a neighborhood assessment, it is reasonable to expect that existing homeowners might be more inclined to remain in their homes when an assessment is not immediate. In the absence of any tax differential the current homeowner remains in his or her home in year $t$ if

$$
V_{t}^{0}+M_{t}^{0}>V_{t}^{\prime}
$$

where $V_{t}^{0}$ is the value placed on the home by the homeowner in year $t, M_{t}^{0}$ is the present value of moving costs, and $V_{t}^{\prime}$ is the market value of the home, that is, the value placed on the home by the highest bidder (other than the current owner).

Differences in the property tax payments of the current homeowner and what the homeowner would pay if she were to move will affect her willingness to sell the home and lose the tax advantage. In this case the household will not move if

$$
V_{t}^{0}+M_{t}^{0}-\Delta P_{t}>V_{t}^{\prime}
$$

where the difference in tax payments between the current and a new homeowner is $\Delta P_{t}<0$. 
This difference, as well, reflects the additional tax payments the current owner would pay if moving to another house of equivalent value. Then assuming that the valuation of the current owner reflects the market but has an idiosyncratic (randomly distributed) component, let

$$
V_{t}^{o}=V_{t}^{\prime}+\varepsilon_{t}^{o}
$$

Then the current owner will not sell if

$$
V_{t}^{\prime}+\varepsilon_{t}^{o}+M_{t}^{0}-\Delta P_{t}>V_{t}^{\prime}
$$

As $\varepsilon_{t}^{o}$ is randomly distributed, we can express the probability that the current household remains in its home as

$$
P\left(\varepsilon_{t}^{0}>\Delta P_{t}-M_{t}^{0}\right)
$$

The larger the difference in tax payments $\left(\Delta P_{t}\right.$ more negative), the smaller can be and still have the household remain in the house. Finally, substituting (4) for $\Delta P_{t}$ in $(9)$ gives

$$
P\left(\varepsilon_{t}^{0}>p V^{0}\left(1-(1+a)^{t-T^{0}}\right) \sum_{s=t}^{T}\left[\frac{(1+l)}{(1+r)}\right]^{s-t}-M_{t}^{0}\right)
$$

suggesting how the probability of selling is a function of the length of time since assessment $\left(t-T^{0}\right)$, the market appreciation rate $(a)$, and the assessment appreciation rate $(l)$.

\section{Data}

\subsection{Sources}

Our source of data is the Property Valuation Administrator (PVA) in Fayette County, Kentucky (Lexington). We obtained these data for virtually all parcels in the county. These data are unique in a number of respects. First, they are unusually detailed. In addition to reporting current tax assessment, parcel identification, street address, house and lot characteristics, all tax assessments from 2001 onward are available. Legal transactions (such as arms-length sales, quit claim deeds arising from divorce, foreclosure proceedings, etc.), along with relevant dates, parties and prices, are also recorded. Second, each parcel is classified into one of approximately 500 neighborhoods within Fayette County. As shown below, this is vital to our identification strategy, because parcels are assessed at different times based on the neighborhood in which they are classified. Finally, access to the data is unusually open compared to other Kentucky counties. The detailed data we utilize is freely available 
at the public website www.fayettepva.com. In addition to the website - which is certainly well-known within the Lexington community - the PVA (an elected official) makes efforts to educate the public on the process of property assessment and changes in property values with the county.11 In comparison, other Kentucky counties restrict public access to their data. One can obtain only superficial information on parcels in Louisville, Kentucky from their free public website (current owner, parcel identification, current assessed value, acreage, and neighborhood); access to the full data requires paying a subscription fee (see http://jeffersonpva.ky.gov).

In all, we collected information on 109,077 parcels (residential, commercial, farms, etc.). Because our algorithm to measure home sales looks at all sales transactions with positive dollar amounts, it is critical to focus on neighborhoods without much new construction. In the PVA data, it is often the case that construction companies will reorganize and "resell" their parcels to subsidiaries. To avoid this, we focus on large neighborhoods (50 or more residential, single-family dwellings) where the overwhelming majority of homes (95 percent or more) were built prior to 2000. In addition, we also restrict attention to the older homes within those neighborhoods. This ultimately leads a sample of 41,276 residential homes located in 125 large neighborhoods. Figure 1 plots these parcels in Lexington. As can be seen, much of our sample is located in the southern half of Lexington, with little representation near the downtown area (where condominiums and town homes are more prevalent).

\subsection{Institutional Details: Tax Assessment in Lexington and Iden- tification Strategy}

In Lexington, there are seven tax districts for single-family residential homes with modest variation in the tax rates between them - ranging from 0.92 percent to 1.10 percent of assessed value in 2010. The variation arises in large part because some neighborhoods rely on private garbage collection, street cleaning and street light maintenance. Newer neighborhoods cannot opt-out of these public services, and if a neighborhood switches from private services to public services, that switch is irreversible. For neighborhoods that use public services, payment is a function of a home's assessed value. For example, a homeowner would pay an additional $\$ 715$ in property taxes per year for public garbage collection on a $\$ 500,000$ home in 2010 , but only $\$ 143$ per year on a $\$ 100,000$ home for essentially identical services.

\footnotetext{
${ }^{11}$ For example, the PVA writes articles for neighborhood magazines like Chevy Chaser Magazine (www.chevychaser.com and Southsider Magazine that provide information on upcoming assessments, the process for appeals, and changes in house values. Both the local newspaper (www.kentucky.com) and nationally recognized real estate web sites (www.zillow.com) draw upon the Fayette PVA's data feed to attach property characteristics to an address.
} 
In neighborhoods that rely on private collection, the private rates almost certainly do not vary as a function of the home's assessed value, but rather based on costs and the bargaining ability of the neighborhood. Of the homes in our sample, almost seventy percent get full public services and pay the highest tax rate.

Kentucky law (KRS.132.690) states that each parcel will be assessed annually by the PVA at its fair cash value in accordance with standards prescribed by the Revenue Cabinet. In addition, property will be physically examined no less than once every four years by the PVA. In practice, houses in Fayette county are assessed the tax year following a sale. As well, neighborhood assessments are usually updated once every four years. If a Lexington neighborhood, in aggregate, has unusually high appreciation or depreciation in values, then neighborhood assessments may be updated more than once every four years. Given the large number of parcels in Fayette county (more than 100,000), the limited resources of the PVA office, and the modest historical year-to-year appreciation in property values in Lexington, the overwhelming majority of non-selling homes are assessed every four years with the PVA making it known well in advance when neighborhoods will be assessed.

Table 4 shows the consequences of this law. Approximately one-quarter of homes in Fayette County are assessed each year, and in most cases, it is clear which neighborhoods are assessed. This table shows the fraction of single family residential homes in a neighborhood that had a different assessment value in a given year, relative to the prior year, for the fifteen largest neighborhoods used in our analysis from 2002 to 2008. Although our data spans the years 2001 to 2009, very few properties changed tax assessments in the final years due to the weak housing market. We cannot present statistics for changes in assessments for 2001 because we do not have assessments from the previous year. Consider the first neighborhood listed, "Garden Springs." In 2003 and 200\%, more than 90 percent of the parcels had changes (almost always increases) in their assessed values. In the other years, fewer than 10 percent of parcels had changes, presumably due to home sales or property improvements. In contrast, the next neighborhood "Rookwood \& Kenwood" had large, wholesale assessments in 2002 and 2005.

Our identification strategy - an important contribution of our paper - is motivated by this table. In older, more established neighborhoods, it is easy to see when wholesale assessments occurred (at least as long as property values were increasing, rather than remaining stagnant). The fact that houses in one neighborhood are assessed in a given year, whereas houses in another nearby neighborhood are not, creates plausibly credible variation in property tax burdens for an individual homeowner. This allows us to construct a "difference-indifferences" estimator of the impact of assessment on moving behavior, using the differential timing of assessments across neighborhoods to estimate this effect. 
Several comments about our approach are in order. First, we are ultimately inferring that a neighborhood was subject to assessment based on observed changes in assessments in that neighborhood. Some neighborhoods were certainly subject to assessment under Kentucky law, but the assessed house values were not ultimately updated when the housing market slowed in later years. Our procedure will have difficulty in detecting these neighborhoods and assessment years. For example, the "Cardinal Valley" neighborhood in Table 4 clearly had a wholesale assessment in 2004 (86 percent of parcels), but only a trivial amount of assessment in 2008. Put differently, our approach detects binding neighborhood assessments, but not non-binding neighborhood assessments ${ }^{12}$ Of course, one may expect that much of home selling behavior should be related to the binding, scheduled assessments. Second, we define a threshold of seventy percent in a neighborhood as a binding, scheduled neighborhood assessment 13 Note that assessments can occur for two main reasons: "wholesale" neighborhood assessment and as a result of individual property sales (which is the outcome of interest). The assessment percentage in Table 4 includes both.

\subsection{Summary Statistics}

Table 5 provides summary statistics on sales, assessed values, and tenure for the sample of single-family dwellings we utilize in our estimation. Table 10 provides additional summary statistics on the characteristics of the dwellings, other variables employed in our estimation strategy but not our focus. From Table 5 we can see at approximately 6.5 percent of houses are sold each year. As well, we consider the distribution of sales conditional on the house being in a neighborhood being assessed that year. Then from the table we see that the percentage of houses sold in neighborhoods being assessed is virtually identical to sales rate when not conditioning on neighborhood assessment. However, approximately 7.8 percent of houses are sold the year before neighborhood assessment and 30.5 percent two years before neighborhood assessment. The year following assessment approximately 6.2 percent of houses are sold.

Figure 2 has the mean sale value versus mean fair cash (assessed) value for the entire sample from 2002 to 2008. The figure suggests similar appreciation of both sale and assessed values during this period. In fact, sales prices increased by 26.9 percent during this period while assessed values increased by 23.3 percent. On an annual basis, this is an increase of 3.97 percent in sale price versus a 3.49 percent increased in assessed values.

\footnotetext{
${ }^{12}$ We have obtained data from the Fayette PVA from 2004 onward that shows us which neighborhoods were subject to assessment, which will allow us to explore the effects of binding versus non-binding assessments more carefully.

${ }^{13}$ We have experimented with other thresholds that are somewhat higher and lower as well with similar results.
} 
The mean assessed (fair cash) value for our sample of houses was $\$ 151,040$. As much of our empirical analysis employs sub-samples of the properties based on neighborhood average assessed value, we provide additional information about the distribution of assessed values. Mean tenure was 12.05 years with approximately 7.5 percent of households being in their house less than a year and over twenty-five percent in their households for over eighteen years. Finally, 17.74 percent of households received a property tax exemption, either based on age or disability, with the mean exemption of $\$ 5,205$.

\section{Empirical Framework}

There are a number of well-recognized empirical problems in the lock-in literature that make it challenging to estimate the causal effect of property taxes on mobility. As Shan (2010) notes, property taxes are likely endogenous to moving decisions, and the net property tax burden is certainly measured with error. Owners who pay high property taxes (and consume higher levels of services) may have different mobility rates than owners who pay low property taxes. For example, homeowners with children may choose to live in areas with higher property tax levels if those taxes are used to fund public schools, and families with children likely have lower mobility rates than other households ${ }^{14}$ The goal of most researchers, then, has been to find an exogenous source of variation that affects the net property tax burden but is otherwise uncorrelated with latent mobility. In our case, the fact that most parcels are assessed every four years, and on a staggered basis, provides exogenous variation in the gross and net tax burden.

\subsection{Tenure and Assessment}

As discussed in Section 3, the extent of "lock-in" will depend on the extent of the expected increase in assessed value and, therefore, property taxes due to automatic assessment. As also discussed, if households with longer tenures might be assessed at levels below market value, the extent of "lock-in" should increase, that is, the difference between assessed values for existing households and the assessed value, equal to market value, for new homeowners. To determine the extent that both tenure and automatic assessment affect assessed property value we estimate a regression of the form

$$
L N\left(P V_{h n t}\right)=\gamma_{0}+\gamma_{1} N A_{n t}+\gamma_{2} N A_{n t-1}+\gamma_{3} \text { Tenure }_{h t}+\gamma_{4} X_{h}+\mu_{n}+\mu_{t}+\varepsilon_{h n t},
$$

\footnotetext{
${ }^{14}$ Shan (2010) finds smaller OLS estimates than IV estimates due to this omitted variables bias.
} 
where $P V_{h n t}$ is assessed property value, $N A_{n t}$ is a dummy variable equal to 1 if a neighborhood was assessed in year $t, X_{h}$ represents house characteristics found in the PVA data (including square footage, lot size, year built, basement characteristics, garage characteristics, exterior wall characteristics, bedrooms, bathrooms, fixtures, heating type, and others), and Tenure is the length of time the current homeowner has been in the home. The terms $\mu_{n}$ and $\mu_{t}$ are dummy variables for neighborhood and time period.

\subsection{Neighborhood Assessment and Mobility}

Following the approach of Ihlanfeldt (2011), we use a linear probability model to obtain the reduced-form "difference-in-differences" estimator of the impact of assessment on the probability of a sale. The model takes the form

$$
\text { Sale }_{h n k}=\beta_{0}+\beta_{1} N A_{n t}+\beta_{2} X_{h}+\delta_{n}+\delta_{k}+\varepsilon_{h n k}, k=t-2, t-1, t, t+1
$$

where Sale $_{h n k}$ is a dummy variable equal to 1 if a home sold in year $k$, and $\delta_{n}$ and $\delta_{t}$ are dummy variables for neighborhood and time period.

As (12) indicates, we estimate separate regressions relating the impact of whether a neighborhood assessment on the probability of a sale in the year of the assessment $(k=t)$, a year preceding the assessment $(k=t-1)$, two years prior to a assessment $(k=t-2)$, and, as a form of falsification test, a year after the assessment $(k=t+1)$.

\subsection{Robustness}

Our primary approach to estimating the impact of the timing of automatic assessment on lock-in, that is, on the probability of a sale follows the difference-in-difference approach of Ihlanfeldt (2011) as described by (12). As a robustness check, we estimate an alternative linear probability model of the form,

$$
\text { Sale }_{h n t-1}=\alpha_{0}+\alpha_{1} \text { Sale }_{h n t-2}+\alpha_{2} N A_{n t}+\alpha_{3} \text { Tenure }_{h n t}+\alpha_{4} X_{h}+\delta_{n}+\delta_{t}+\epsilon_{h n t}
$$

Estimation of (13) enables us to consider the impacts of recent sales and tenure on the probability of a sale as well as automatic assessment.

\subsection{Estimation Techniques}

The structure of our data, a panel of parcels observed over a period of seven years in identified and well-defined neighborhoods suggests, as illustrated in the specifications of our estimating equations, (11) and (12), suggests the existence of correlation across "clusters", in our case, 
two clusters - the neighborhood and year. This correlation means that the standard errors obtain with simple $O L S$ are not robust. To address these concerns, we follow the procedure outlined in Cameron, Gelbach and Miller (2011) 15

Our estimation to check for the robustness of the estimates based on (11) and (12) relies on estimating (13) using panel techniques - fixed and random effect estimation and, because there is a lagged dependent variable in some specifications, Arellano-Bond estimation as well 16

\section{Results}

\subsection{Tenure and Assessment}

Tables 6 and 7 provide the results of estimating (11) for alternative average neighborhood assessed value and alternative specifications of tenure. The dependent variable $L N$ (Fair Cash Value) is the assessed value of the property but differs from the taxable value when the property owner receives an exemption. All regressions include year and neighborhood fixed effects and a vector of housing characteristics listed in Table 10. There are 125 neighborhoods and 7 years. The threshold for assigning a neighborhood as being in a "Assessment Year" is that seventy percent of the parcels in the neighborhood have changes in their assessment.

In Table 6 tenure is measured in number of years. As can be seen in the table the impact of a year of tenure varies with the average neighborhood property value (and, therefore, presumably the value of the property). As Tenure is interacted with Neighborhood Assessment $_{t-1}$ this interaction needs to be considered as well to understand the impact of an additional year on tenure. As the coefficients on Assessment $t_{-1}{ }^{*}$ Tenure indicate, houses with residents with long tenures face a slightly higher (percentage) assessment. The net effect of tenure, accounting for neighborhood assessment occurring every four years is found in the row labeled $\beta_{T}+.25 * \beta_{R_{t-1}+T}$ and, as well, Figure 3. In the sample, a year of tenure decreases assessed value by 0.185 percent. With the exception of neighborhood assessed values in the $25^{t h}-50^{t h}$ percentile, tenure, on net, reduces assessed valuation in neighborhoods across the distribution of average assessed value. The smallest impact is a 0.12 percent reduction for houses in neighborhoods in the $25^{\text {th }}$ percentile or below while houses in the neighborhoods in the $90^{\text {th }}$ percentile or above see a yearly decrease of 0.36 percent.

As expected, assessment increases assessed value, by 5.9 percent (over four years) in the full sample with the (percentage) increase in assessed value decreasing with average neigh-

\footnotetext{
${ }^{15}$ This procedure can be done in Stata using the command cgmreg.

${ }^{16}$ More precisely, in the Arellano-Bond estimation we use a one-step difference GMM. (xtabond2 in Stata)
} 
borhood assessed value. Note that while this is not an insignificant increase in assessment, the mean rate of appreciation based on sales was 3.9 percent annually (or 16.5 percent over four years). As also expected, houses in neighborhoods that were assessed the year before $(t-1)$ have higher assessed values than those assessed two or three years early, the omitted assessment years, but not as significant as those assessed this year (4.17 percent for the full sample). Finally, note that households that receive an property tax exemption have, in the full sample, assessments that are 1.26 percent higher than houses with similar characteristics and in the same neighborhoods. The magnitude of this increase in assess-

ment is relatively stable across the spectrum of average neighborhood assessed values though statistically-insignificant for houses in neighborhoods in the $90^{\text {th }}$ percentile or above.

In Table 7 we include four distinct periods for tenure: 2- 4 years, 5- 8 years, 9 - 18 years, and $>18$ years with tenure of less than two years the omitted category. The results are generally consistent with what we report in 6 with tenure treated as a continuous variable. Tenure leads to significantly lower assessed values - for the full sample a reduction of 4.7 percent with tenure of just two to four years and 9 percent for tenure of over 18 years. For houses in the most expensive (highly-assessed) neighborhoods the difference after two to four years is 5.9 percent and almost 15 percent for over eighteen years. Inspection of the table and tests of coefficient equality suggest that most of the impact of tenure on assessed value occurs in the first 17 years with insignificant impacts on assessment for longer tenures.

\subsection{Assessment and Mobility}

In Table 8 we report the coefficient on Neighborhood Assessment for the twenty-four regressions, six alternative specifications with each of our four alternative dependent variables (year in which the property was sold), we estimated using a linear probability model. Column (a) reports the results for our simplest specification with Neighborhood Assessment being the only explanatory variable. Column (b) also includes year dummies, column (c) includes neighborhood dummies, column (d) has both year and neighborhood dummies while column (e) includes both year and neighbor dummies as well as the interaction of the two variables. Column (f) includes the exemption as well as the alternative forms of neighborhood and year dummies. Finally, column $(g)$ adds housing characteristics.

Our results are quite robust across specifications. As expected, for none of the specifications in which the dependent variable is not Sold Last Year $(k=t-1)$ is the coefficient on Neighborhood Assessment statistically significant. In contrast, with a dependent variable of Sold Last Year $(k=t-1)$, we find the coefficient on Neighborhood Assessment to be significant in all specifications except when only year dummies were included (column (b)) and in all 
cases the coefficient is positive as expected. The coefficient on Neighborhood Assessment in the specifications reported in columns $(\mathrm{d})$ - (f), are virtually identical at 0.0035 . Then with a mean mobility (sales) rate of $6.50 \%$, mobility in the year before neighborhood assessment increases to approximately $6.85 \%$. Figure 4 provides an illustration of the magnitude of the coefficient on Neighborhood Assessment in specification (g) for the alternative years of sale.

While the positive and significant coefficient on Neighborhood Assessment with Sold Last Year as the dependent variable indicates a concentration of sales before a neighborhood assessment on a four year cycle, less clear is whether the increase in sales the year before the assessment is due to a delay in sale to capture another year of reducing property tax obligations or a earlier sale than otherwise to avoid the higher tax payment associated with the assessment. For both the dependent variable Sold Two Years Ago and Sold This Year the coefficient on Neighborhood Assessment is generally negative but not statistically significant.

\subsubsection{Robustness Checks}

As an alternative approach, we estimate the impacts of automatic assessment on the probability of a sale using panel techniques to estimate forms of (13). The results of this estimation is found in Table 9. In all cases the dependent variable is Sold Last Year $(k=t-1)$ with Neighborhood Assessment in year $t$ the variable of interest. Given the use of panel techniques, our specifications are quite parsimonious, additional variables in alternative specifications include Sold 2 Years Ago, Tenure, and Tenure ${ }^{2}$.

Our first set of estimates are doing using a fixed effects model. The results are generally consistent with the results found in Table 8 - in three of the five specifications the coefficient on Neighborhood Assessment is positive and statistically-significant. The range of the coefficient on Neighborhood Assessment is from -.00002 to 0.0071 with the range on the more

precisely-estimated coefficients from 0.00568 to 0.0071 , larger than the estimate of 0.0035 found in Table 8, specification ( $\mathrm{g})$.

The next set of estimates are done using a random effects model. Again, the results are similar to those found in Table 8 with positive and statistically-significant coefficients on Neighborhood Assessment that range from 0.0035 to 0.0054 ,

Finally, given the inclusion of a lagged dependent variable Sold 2 Years Ago we estimate two specifications of the model using Arellano-Bond procedures. Again, we find positive and statistically-significant coefficients on Neighborhood Assessment. 


\section{Conclusion}

Consistent with our expectations and evidence from other studies of "lock in", we find that the practice of neighborhood assessments on a regular multi-year interval (in the case of Lexington, four years) or upon sales appear to affect household mobility. From our examination of the determinants of assessed (fair cash) value, we find that assessed value is lower the longer the tenure of the resident. As well, that neighborhood assessments during the period 2002 to 2008 lead to significant increases in assessed value with the increases higher for houses in which residents had longer tenure, suggesting that assessment will have a significant impacts on the property tax payments of current residents.

Our results suggest that mobility is significantly different the year before these automatic, neighborhood assessments but not for any of the other years (year of the assessment, two years before, and a year after). While these results suggest that mobility is affected by discrete, automatic assessments it is not obvious as to whether it leads to households postponing moving to capture another year of lower tax obligations or deciding to move earlier to avoid the higher tax payment as a result of the assessment. Theoretically, both cases are possible. Regardless, while long term mobility might be unaffected by the length of the interval between assessments the fact that it does affect short term mobility rates suggests there is an associated welfare cost with the policy. 


\section{References}

Anderson, Nathan B. 2006. "Property Tax Limitations: An Interpretative Review." National Tax Journal, 49(3): 685-694.

Biehl, Amelia S., and William H. Hoyt. 2014. "The Taxpayer Relief Act of 1997 and Homeownership: Is Small Now Better?" Economic Inquiry, 52(2): 646-658.

Bowman, John H. 2006. "Property Tax Policy Responses to Rapidly Rising Home Values: District of Columbia, Maryland, and Virginia." National Tax Journal, 59(3): 717-733.

Bradbury, Katharine L., Christopher J. Mayer, and Karl E. Case. 2001. "Property Tax Limits, Local Fiscal Behavior, and Property Values: Evidence from Massachusetts under Proposition 21/2." Journal of Public Economics, 80: 287-311.

Bradley, Sebastien. 2016. "Assessment Limits and Timing of Real Estate Transactions." Regional Science and Urban Economics.

Cabral, Marika, and Caroline Hoxby. 2015. "The Hated Property Tax: Salience, Tax Rates, and Tax Revolts." Working Paper.

Cameron, Colin, Jonah Gelbach, and Douglas Miller. 2011. "Robust Inference with Multi-Way Clustering." Journal of Business and Economic Statistics, 29(2): 238-249.

Cornia, Gary C., and Lawrence C. Walters. 2006. "Full Disclosure: Controlling Property Tax Increases During Periods of Increasing Housing Values." National Tax Journal, 49(3): 735-749.

Cunningham, Christopher R., and Gary V. Engelhardt. 2008. "Housing CapitalGains Taxation and Homeowner Mobility: Evidence from the Taxpayer Relief Act of 1997." Journal of Urban Economics, 63: 803-815.

Cutler, David M., Douglas W. Elmendorf, and Richard Zeckhauser. 1999. "Restraining the Leviathan: Property Tax Limitation in Massachusetts." Journal of Public Economics.

Dye, Richard F., Daniel P. McMillen, and David F. Merriman. 2006. "Illinois's Response to Rising Residential Property Values: An Assessment Growth Cap in Cook County." National Tax Journal, 59(3): 707-716. 
Ferreira, Fernando V. 2010. "You Can Take it with You: Proposition 13 Tax Benefits, Residential Mobility, and Willingness to Pay for Housing Amenities." Journal of Public Economics, 94: 661-673.

Gyourko, Joseph A., Christopher Mayer, and Todd Sinai. 2013. "Superstar Cities." American Economic Journal: Economic Policy, 5(4): 167-199.

Haveman, Mark, and Terri A. Sexton. 2008. Property Tax Assessment Limits: Lessons from Thirty Years of Experience. Lincoln Institute of Land Policy.

Hodge, Timothy R., Gary Sands, and Mark Skidmore. 2015. "Assessment Growth Limits and Mobility: Evidence from Home Sale Data in Detroit, Michigan." National Tax Journal, 68(3): 573-600.

Hodge, Timothy R., Mark Skidmore, Gary Sands, and Daniel P. McMillen. 2015. "Tax Base Erosion and Inequity from Michigan's Assessment Growth Limit: The Case of Detroit." Public Finance Review, 43(5): 636-660.

Hoyt, William H., Paul A. Coomes, and Amelia S. Biehl. 2011. "Tax Limits and Housing Markets: Some Evidence at the State Level." Real Estate Economics, 39(1): 97132.

Ihlanfeldt, Keith R. 2011. "Do Caps on Increases in Assessed Values Create a Lock-In Effect? Evidence from Florida's Amendment One." National Tax Journal, 64(1): 7-26.

Land, Mark H., and Douglas A. Shackelford. 2000. "Capitalization of Capital Gains Taxes: Evidence from STock Price Reactions to the 1997 Tax Reductions." Journal of Public Economics, 76: 69-85.

Lang, Kevin, and Tianlun Jun. 2004. "Property Taxes and Property Values: Evidence from Proposition 2 1/2." Journal of Urban Economics, 55: 439-457.

Nagy, John. 1997. "Did Proposition 13 affect the Mobility of California Homeowers?" Public Finance Review, 25(1): 102-116.

Shan. 2010. "Property Taxes and the Elderly." Journal of Urban Economics, 67: 194-205.

Sinai, Todd, and Joseph A. Gyourko. 2002. "The Asset Price Incidence of Capital Gains Taxes: Evidence from the Taxpayer Relief Act of 1997 and Public-traded Real Estate Firms." Journal of Public Economics, 88: 1543-1565. 
Skidmore, Mark, Charles L. Ballard, and Timothy R. Hodge. 2010. "Property Value Assessment Growth Limits and Redistribution of Property Tax Payments: Evidence from Michigan." National Tax Journal, 63(3): 509-538.

Stansel, Dean B., Gary Jackson, and J. Howard Finch. 2007. "Housing Tenure and Mobility with an Acquisition-Based Property Tax: The Case of Florida." Journal of Housing Research, 16(2): 117-129.

Stohs, Mark Hoven, Paul Childs, and Simon Stevenson. 2001. "Tax Policies and Residential Mobility." International Real Estate Review, 4(1): 95-117.

Wasi, Nada, and Michelle J. White. 2005. "Property Tax Limitations and Mobility: Lock-In Effect of California's Proposition 13." , ed. Gary Burtless and Janet Rothenberg Pack Vol. 6 of Brookings-Wharton Papers on Urban Affairs, 59-88. Washington, DC:Brookings Institution Press. 
Figure 1: Geographic Coverage in Lexington, $K Y$

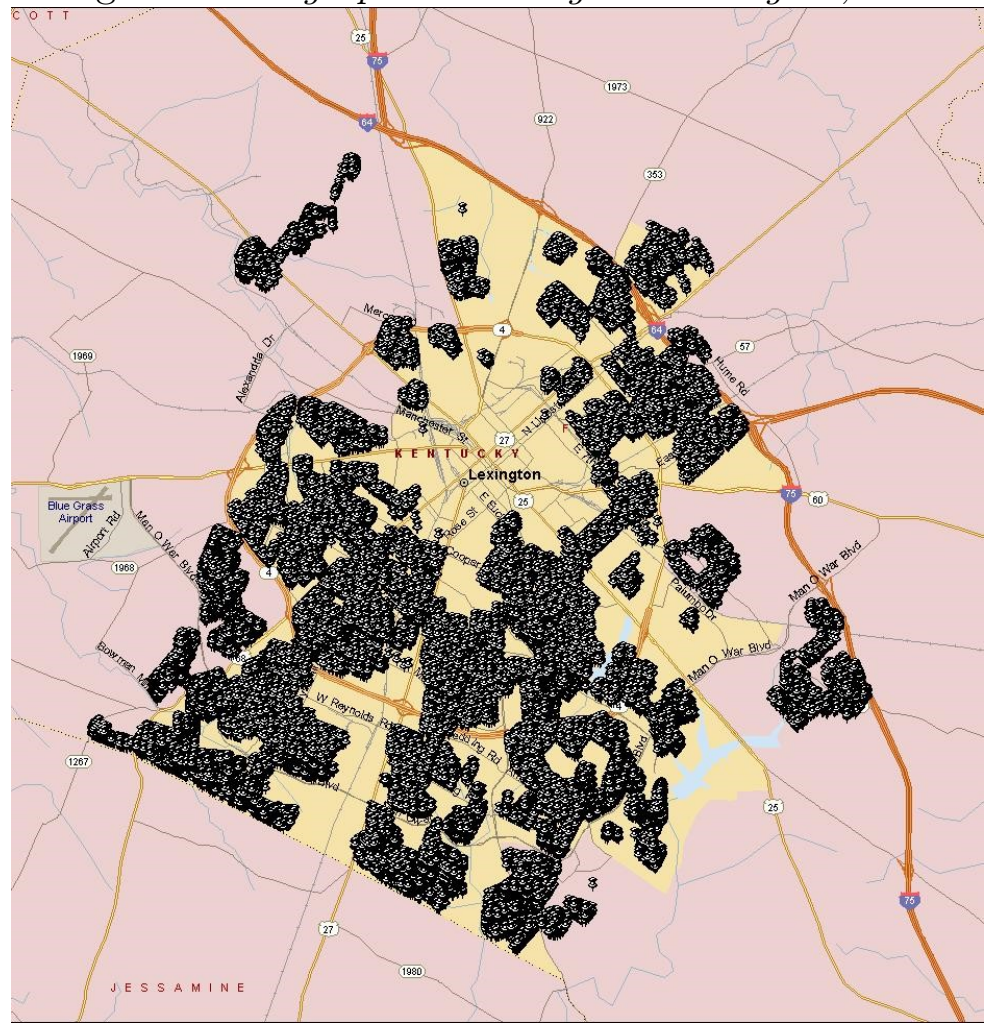

Figure 2: Sales Price vs. Assessed Value, 2002 - 2008

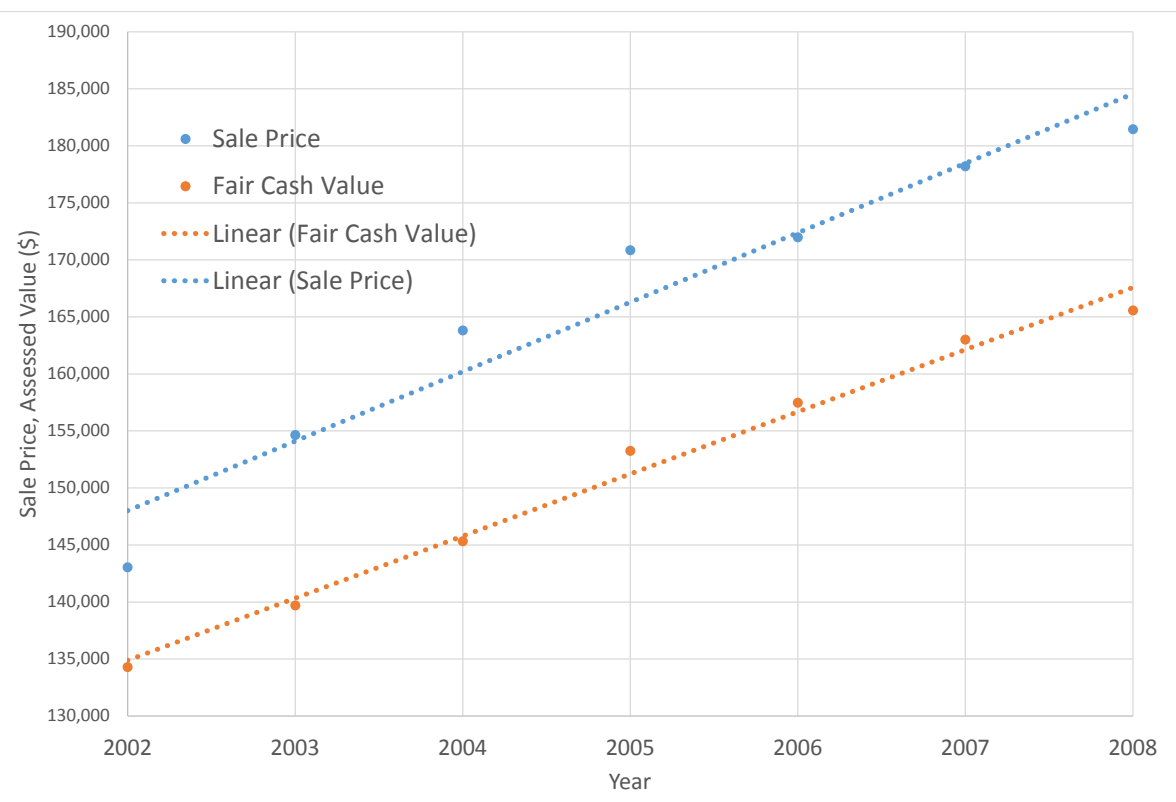


Figure 3: Impact of Tenure on Assessed Value, Annual Percentage Change by Average Neighborhood Assessed Value

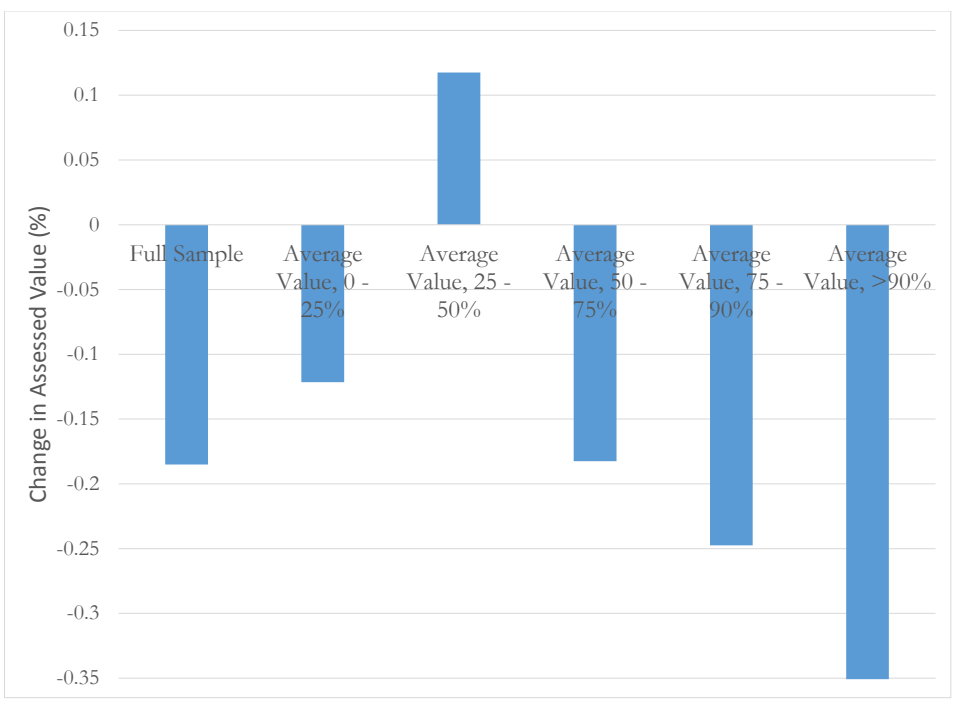

Figure 4: Impact of Assessment on Change in Probability of Sale (Table 8; specification ( $\mathrm{g}$ ))

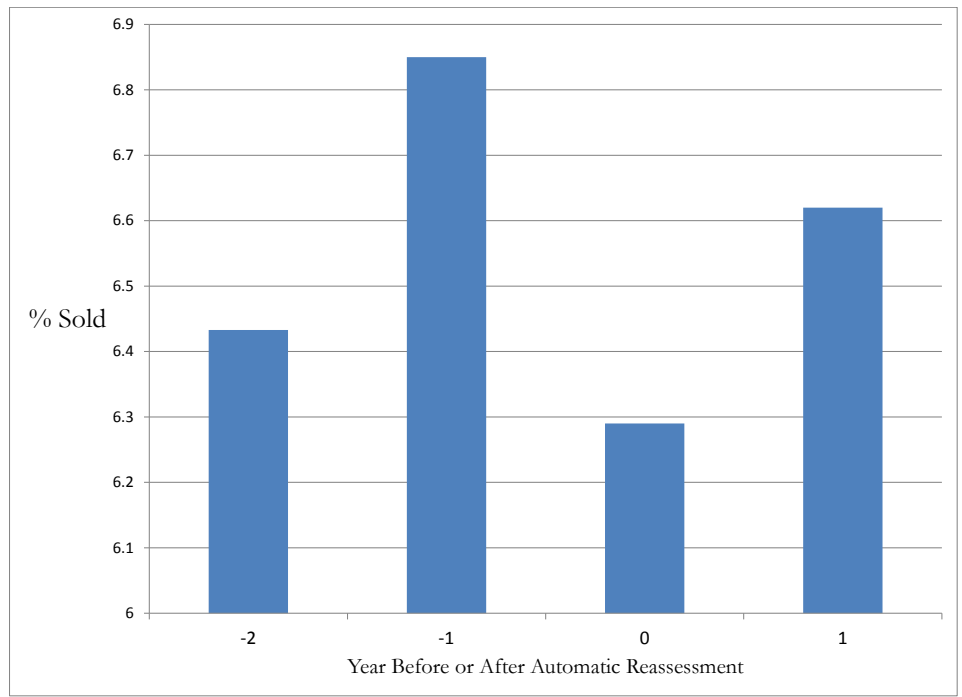


Table 1: Differences in Annual Tax Payments based on Time from Neighborhood Assessment, By Value, Tax Rate, and Appreciation

\begin{tabular}{|c|c|c|c|c|}
\hline \multirow{2}{*}{$\begin{array}{l}\text { Tax } \\
\text { Rate }\end{array}$} & \multirow[b]{2}{*}{ Appreciation } & \multicolumn{3}{|c|}{ Annual Change in Tax Payment } \\
\hline & & $\Delta 1$ & $\Delta 2$ & $\Delta 3$ \\
\hline 0.01 & \multirow{3}{*}{0.03} & 45 & 91 & 139 \\
\hline 0.015 & & 68 & 137 & 209 \\
\hline 0.02 & & 90 & 183 & 278 \\
\hline 0.01 & \multirow{3}{*}{0.05} & 75 & 154 & 236 \\
\hline 0.015 & & 113 & 231 & 355 \\
\hline 0.02 & & 150 & 308 & 473 \\
\hline 0.01 & \multirow{3}{*}{0.10} & 150 & 315 & 497 \\
\hline 0.015 & & 225 & 473 & 745 \\
\hline 0.02 & & 300 & 630 & 993 \\
\hline 0.01 & \multirow{3}{*}{0.03} & 90 & 183 & 278 \\
\hline 0.015 & & 135 & 274 & 417 \\
\hline 0.02 & & 180 & 365 & 556 \\
\hline 0.01 & \multirow{3}{*}{0.05} & 150 & 308 & 473 \\
\hline 0.015 & & 225 & 461 & 709 \\
\hline 0.02 & & 300 & 615 & 946 \\
\hline 0.01 & \multirow{3}{*}{0.10} & 300 & 630 & 993 \\
\hline 0.015 & & 450 & 945 & 1,490 \\
\hline 0.02 & & 600 & 1,260 & 1,986 \\
\hline 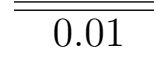 & \multirow{3}{*}{0.03} & $\bar{~} 180$ & 365 & 2556 \\
\hline 0.015 & & 270 & 548 & 835 \\
\hline 0.02 & & 360 & 721 & 1,113 \\
\hline 0.01 & \multirow{3}{*}{0.05} & 300 & 615 & 946 \\
\hline 0.015 & & 450 & 923 & 1,419 \\
\hline 0.02 & & 600 & 1,230 & 1,892 \\
\hline 0.01 & \multirow{3}{*}{0.10} & 600 & 1,260 & 1,986 \\
\hline 0.015 & & 900 & 1,890 & 2,979 \\
\hline 0.02 & & 1,200 & 2,520 & 3,972 \\
\hline
\end{tabular}


Table 2: Differences in Present Value of Tax Payments based on Time from Neighborhood Assessment, By Value, Tax Rate, and Appreciation

\begin{tabular}{|c|c|c|c|c|c|}
\hline \multirow[t]{2}{*}{ Values } & \multirow{2}{*}{$\begin{array}{l}\text { Tax } \\
\text { Rate }\end{array}$} & \multirow{2}{*}{ Appreciation } & \multicolumn{3}{|c|}{$\begin{array}{c}\text { Difference in Present Value, } \\
\text { Years from Neighborhood Assessment }\end{array}$} \\
\hline & & & 1 & 2 & 3 \\
\hline \multirow{9}{*}{150,000} & 0.01 & \multirow{3}{*}{0.03} & 130 & 179 & 139 \\
\hline & 0.015 & & 195 & 269 & 209 \\
\hline & 0.02 & & 260 & 358 & 278 \\
\hline & 0.01 & \multirow{3}{*}{0.05} & 216 & 302 & 236 \\
\hline & 0.015 & & 325 & 452 & 355 \\
\hline & 0.02 & & 433 & 603 & 473 \\
\hline & 0.01 & \multirow{3}{*}{0.10} & 433 & 618 & 497 \\
\hline & 0.015 & & 649 & 927 & 745 \\
\hline & 0.02 & & 866 & 1,236 & 993 \\
\hline \multirow{9}{*}{300,000} & 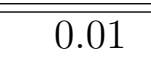 & \multirow{3}{*}{0.03} & 260 & 358 & 278 \\
\hline & 0.015 & & 390 & 538 & 417 \\
\hline & 0.02 & & 519 & 717 & 556 \\
\hline & 0.01 & \multirow{3}{*}{0.05} & 433 & 603 & 473 \\
\hline & 0.015 & & 649 & 905 & 709 \\
\hline & 0.02 & & 866 & 1,206 & 946 \\
\hline & 0.01 & \multirow{3}{*}{0.10} & 866 & 1,236 & 993 \\
\hline & 0.015 & & 1,299 & 1,854 & 1,490 \\
\hline & 0.02 & & 1,732 & 2,472 & 1,986 \\
\hline \multirow{9}{*}{600,000} & 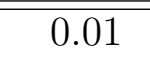 & \multirow{3}{*}{0.03} & 519 & 717 & 556 \\
\hline & 0.015 & & 779 & 1,075 & 835 \\
\hline & 0.02 & & 1,039 & 1,433 & 1,113 \\
\hline & 0.01 & \multirow{3}{*}{0.05} & 866 & 1,206 & 946 \\
\hline & 0.015 & & 1,299 & 1,810 & 1,419 \\
\hline & 0.02 & & 1,732 & 2,413 & 1,892 \\
\hline & 0.01 & \multirow{3}{*}{0.10} & 1,732 & 2,472 & 1,986 \\
\hline & 0.015 & & 2,597 & 3,707 & 2,979 \\
\hline & 0.02 & & 3,463 & 4,943 & 3,972 \\
\hline
\end{tabular}


Table 3: Differences in Annual and Present Value of Tax Payments with Limited Increases in Assessment, by Appreciation and Tax Rate ${ }^{1}$

\begin{tabular}{|c|c|c|c|c|c|}
\hline $\begin{array}{c}\text { Appreciation } \\
\text { Rate }\end{array}$ & $\begin{array}{c}\text { Market } \\
\text { Value }\end{array}$ & $\begin{array}{l}\text { Appraised } \\
\text { Value }\end{array}$ & Tax Rate & $\begin{array}{c}\text { Annual } \\
\text { Tax } \\
\text { Difference }\end{array}$ & $\begin{array}{c}\text { Present } \\
\text { Value of } \\
\text { Tax } \\
\text { Difference }\end{array}$ \\
\hline \multirow{3}{*}{0.024} & \multirow{3}{*}{380,295} & \multirow{3}{*}{365,698} & 0.01 & 146 & 373 \\
\hline & & & 0.015 & 219 & 560 \\
\hline & & & 0.02 & 292 & 747 \\
\hline \multirow{3}{*}{0.03} & \multirow{3}{*}{403,175} & \multirow{3}{*}{365,698} & 0.01 & 375 & 1,232 \\
\hline & & & 0.015 & 562 & 1,847 \\
\hline & & & 0.02 & 750 & 2,463 \\
\hline \multirow{3}{*}{0.05} & \multirow{3}{*}{488,668} & \multirow{3}{*}{365,698} & 0.01 & 1,230 & 7,390 \\
\hline & & & 0.015 & 1,845 & 11,085 \\
\hline & & & 0.02 & 2,459 & 14,780 \\
\hline \multirow{3}{*}{0.075} & \multirow{3}{*}{618,309} & \multirow{3}{*}{365,698} & 0.01 & 2,526 & 25,612 \\
\hline & & & 0.015 & 3,789 & 38,419 \\
\hline & & & 0.02 & 5,052 & 51,225 \\
\hline
\end{tabular}

${ }^{1}$ Based on 10 years of prior ownership and 10 years of future ownership. Original assessed and market value is $\$ 300,000$. The rate of assessment increases is 0.02 . 
Table 4: Fraction of Homes Assessed from Prior Year ${ }^{1}$

\begin{tabular}{c|c|c|c|c|c|c|c}
\hline Neighborhood & 2002 & 2003 & 2004 & 2005 & 2006 & 2007 & 2008 \\
\hline \hline Garden Springs & $7 \%$ & 92 & 6 & 8 & 6 & 95 & 8 \\
\hline Rookwood \& Kenwood & 93 & 6 & 6 & 77 & 6 & 5 & 4 \\
\hline Deep Spring Part of Dixie Hermitage Hill & 7 & 6 & 6 & 88 & 5 & 7 & 5 \\
\hline Hollow Creek \& Winburn & 4 & 5 & 4 & 80 & 8 & 7 & 4 \\
\hline The Meadows & 78 & 7 & 7 & 80 & 8 & 7 & 4 \\
\hline Radcliffe & 6 & 82 & 5 & 6 & 7 & 94 & 5 \\
\hline Throughbred & 7 & 87 & 5 & 5 & 6 & 94 & 5 \\
\hline Cardinal Valley & 8 & 6 & 86 & 7 & 6 & 7 & 4 \\
\hline Chevy Chase & 11 & 98 & 13 & 14 & 86 & 11 & 10 \\
\hline Gainesway & 96 & 6 & 8 & 88 & 7 & 4 & 6 \\
\hline Melody Village \& River Park & 97 & 8 & 6 & 7 & 97 & 7 & 4 \\
\hline Southland * Hill N' Dale & 96 & 10 & 9 & 84 & 6 & 6 & 5 \\
\hline Southland \& Rosemill & 7 & 91 & 8 & 9 & 10 & 91 & 9 \\
\hline Gardenside Prospect Hill \& Sky Crest & 7 & 7 & 87 & 9 & 6 & 7 & 6 \\
\hline Autumn Ridge 90 & 10 & 12 & 11 & 90 & 9 & 10 & 7 \\
\hline \hline
\end{tabular}

${ }^{1}$ Notes: This table displays assessment rates for the 15 largest neighborhoods used in the analysis; overall there are 125 neighborhoods that have very little new construction after 2000 and have $50+$ parcels. 
Table 5: Summary Statistics: Assessed Value, Tenure, Sales

\begin{tabular}{|c|c|}
\hline Variable & Mean $/ \%$ \\
\hline Sold in Current Year (\%) & 6.42 \\
\hline \multicolumn{2}{|c|}{ Sale Year Conditional on Neighborhood Assessment } \\
\hline Sold in Year of Assessment (\%) & 6.44 \\
\hline Year before Assessment (\%) & 7.81 \\
\hline 2 Years before Assessment (\%) & 30.51 \\
\hline Year Following Assessment (\%) & 6.23 \\
\hline \multicolumn{2}{|l|}{ Assessed Value } \\
\hline Assessed Value (Mean) & 151,040 \\
\hline Assessed Value, $25^{\text {th }}$ Percentile & 96,000 \\
\hline Assessed, Value, $50^{\text {th }}$ Percentile & 125,000 \\
\hline Assessed Value, $75^{\text {th }}$ Percentile & 174,500 \\
\hline Assessed Value, $90^{t h}$ Percentile & 250,000 \\
\hline \multicolumn{2}{|l|}{ Tenure } \\
\hline Tenure, Years (Mean) & 12.05 \\
\hline Tenure, 1 Year or Less $(\%)$ & 7.45 \\
\hline Tenure $2-4$ Years $(\%)$ & 20.0 \\
\hline Tenure, 5 - 8 Years $(\%)$ & 19.54 \\
\hline Tenure, 9 - 17 Years (\%) & 27.47 \\
\hline Tenure, More than 18 Years $(\%)$ & 25.52 \\
\hline \multicolumn{2}{|l|}{ Exemptions } \\
\hline Exemption, Receiving (\%) & 17.74 \\
\hline Exemption, (Mean Value, \$) & 5,205 \\
\hline
\end{tabular}

Data includes all years from 2002 to 2008. The overall sample has 248,918 observations on 41,276 single family homes. All specification cluster standard errors at the neighborhood- year level (125 unique groups). 
Table 6: LN(Fair Cash Value) on Assessment by Average Neighborhood Assessed Value

\begin{tabular}{|c|c|c|c|c|c|c|}
\hline \multicolumn{7}{|l|}{$(C G M)^{1}$} \\
\hline Variable & Full Sample & $\begin{array}{l}\text { Average } \\
\text { Value, } \\
0-25 \%\end{array}$ & $\begin{array}{l}\text { Average } \\
\text { Value, } \\
25-50 \%\end{array}$ & $\begin{array}{l}\text { Average } \\
\text { Value, } \\
50-75 \%\end{array}$ & $\begin{array}{c}\text { Average } \\
\text { Value, } \\
75-90 \%\end{array}$ & $\begin{array}{l}\text { Average } \\
\text { Value, } \\
\geq 90 \%\end{array}$ \\
\hline Tenure & $\begin{array}{c}-0.0021^{* * *} \\
(8.37)\end{array}$ & $\begin{array}{c}-0.0014^{* * *} \\
(5.40)\end{array}$ & $\begin{array}{c}-0.0023^{* * *} \\
(7.19)\end{array}$ & $\begin{array}{c}-.00202^{* * *} \\
(5.91)\end{array}$ & $\begin{array}{c}-0.0029 * * * \\
(4.89)\end{array}$ & $\begin{array}{c}-0.0041^{* * *} \\
(7.36)\end{array}$ \\
\hline $\begin{array}{l}\text { Neighborhood } \\
\text { Assessment }_{t}\end{array}$ & $\begin{array}{c}0.0590^{* * *} \\
(10.25)\end{array}$ & $\begin{array}{c}0.0712^{* * *} \\
(10.34)\end{array}$ & $\begin{array}{c}0.0614^{* * *} \\
(7.13)\end{array}$ & $\begin{array}{c}0.0562^{* * *} \\
(8.87)\end{array}$ & $\begin{array}{c}0.0489 * * * \\
(7.41)\end{array}$ & $\begin{array}{c}0.0442^{* * *} \\
(3.39)\end{array}$ \\
\hline $\begin{array}{l}\text { Neighborhood } \\
\text { Assessment }_{t-1}\end{array}$ & $\begin{array}{c}0.0417^{* * * *} \\
(9.51)\end{array}$ & $\begin{array}{c}.0465^{* * *} \\
(5.68)\end{array}$ & $\begin{array}{c}0.0460 * * * \\
(5.77)\end{array}$ & $\begin{array}{c}0.0430^{* * *} \\
(5.39)\end{array}$ & $\begin{array}{c}0.0346^{* * *} \\
(8.87)\end{array}$ & $\begin{array}{c}0.0301^{* *} \\
(2.42)\end{array}$ \\
\hline $\begin{array}{c}\text { Neighborhood } \\
\text { Assessment }_{t-1} * \\
\text { Tenure }\end{array}$ & $\begin{array}{c}0.00101^{* * *} \\
(5.84)\end{array}$ & $\begin{array}{c}.00074^{* *} \\
(2.85)\end{array}$ & $\begin{array}{c}0.0139 * * * \\
(5.00)\end{array}$ & $\begin{array}{c}0.00078^{* * *} \\
(3.14)\end{array}$ & $\begin{array}{c}0.0017 * * \\
(2.19)\end{array}$ & $\begin{array}{c}0.0017^{* * *} \\
(4.94)\end{array}$ \\
\hline Exemption & $\begin{array}{c}0.0126^{* * *} \\
(6.18)\end{array}$ & $\begin{array}{c}0.0119^{* * *} \\
(4.13)\end{array}$ & $\begin{array}{c}0.134^{* * *} \\
(3.64)\end{array}$ & $\begin{array}{c}0.0116^{* * *} \\
(3.40)\end{array}$ & $\begin{array}{c}0.0100^{* *} \\
(2.17)\end{array}$ & $\begin{array}{c}0.0140 \\
(1.33)\end{array}$ \\
\hline$\overline{\overline{\beta_{T}+.25 * \beta_{R_{t-1 * T}}}}$ & $-0.0019 * * *$ & $-0.0012^{* * *}$ & $0.0012^{* * *}$ & $-0.0018^{* * *}$ & $-0.0025^{* * *}$ & $-0.0037^{* * *}$ \\
\hline$\overline{\mathrm{N}}$ & 212,537 & $\overline{53,556}$ & 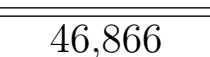 & 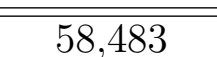 & 31,685 & 21,947 \\
\hline Year Dummies & Yes & Yes & Yes & Yes & Yes & Yes \\
\hline $\begin{array}{c}\text { Neighborhood } \\
\text { Dummies }\end{array}$ & Yes & Yes & Yes & Yes & Yes & Yes \\
\hline $\begin{array}{l}\text { Housing Unit } \\
\text { Characteristics }\end{array}$ & Yes & Yes & Yes & Yes & Yes & Yes \\
\hline
\end{tabular}

${ }^{1}$ Absolute value of the $\mathrm{z}$-statistics are reported in parentheses with ${ }^{* * *}$ significant at a $1 \%$ level, $* *$ at a $5 \%$ level, and $*$ at a $10 \%$ level.

Notes: Data includes all years from 2002 to 2008. There are 125 neighborhoods and 6-7 years depending on the outcome variable. The overall sample has 248,918 observations on 41,276 single family homes. All specifications cluster standard errors at the neighborhood-year level (125 unique groups). Threshold for assigning neighborhood as a "Assessment Year" is that $70 \%$ of parcels have changes in their assessment. Results are robust to other reasonable thresholds. 
Table 7: LN(Fair Cash Value) on Tenure, Assessment, and Exemption, by Average Neighborhood Assessed Value (CGM)

\begin{tabular}{|c|c|c|c|c|c|c|}
\hline Variable & Full Sample & $\begin{array}{l}\text { Average } \\
\text { Value, } \\
0-25 \%\end{array}$ & $\begin{array}{c}\text { Average } \\
\text { Value, } \\
25-50 \%\end{array}$ & $\begin{array}{c}\text { Average } \\
\text { Value, } \\
50-75 \%\end{array}$ & $\begin{array}{c}\text { Average } \\
\text { Value, } \\
75-90 \%\end{array}$ & $\begin{array}{l}\text { Average } \\
\text { Value, } \\
\geq 90 \%\end{array}$ \\
\hline $\begin{array}{c}\text { Tenure, } \\
\text { 2-4 Years }\end{array}$ & $-0.0468^{* * *}$ & $-0.0383^{* * *}$ & $-0.0491^{* * *}$ & $-0.0483^{* * *}$ & $-0.0500^{* * *}$ & $-0.0593^{* * *}$ \\
\hline Tenure, & $-0.0781^{* * *}$ & $-0.0604^{* * *}$ & $-0.0817^{* * *}$ & $-0.781^{* * *}$ & $-0.835^{* * *}$ & $-0.1150^{* * *}$ \\
\hline 5-8 Years & $(9.49)$ & $(7.32)$ & $(8.22)$ & (7.49) & $(6.62)$ & (10.11) \\
\hline Tenure, & $-0.0881^{* * *}$ & $-0.0703^{* * *}$ & $-0.0902^{* * *}$ & $-0.0848^{* * *}$ & $-0.0988^{* * *}$ & $-0.1318^{* * *}$ \\
\hline 9-18 Years & $(-9.49)$ & $(8.35)$ & (8.47) & $(7.78)$ & $(7.21)$ & $(7.58)$ \\
\hline $\begin{array}{l}\text { Tenure, } \\
>18 \text { Years }\end{array}$ & $\begin{array}{c}-0.0908^{* * * *} \\
\quad(9.16)\end{array}$ & $\begin{array}{c}-0.0695^{* * *} \\
(7.09)\end{array}$ & $\begin{array}{c}-0.948^{* * * *} \\
(8.72)\end{array}$ & $\begin{array}{c}-0.0879^{* * *} \\
(7.19)\end{array}$ & $\begin{array}{c}-0.1035^{* * *} \\
(6.74)\end{array}$ & $\begin{array}{c}-0.1467^{* * *} \\
(9.03)\end{array}$ \\
\hline Neighborhood & $0.0712^{* * *}$ & $0.0809^{* * *}$ & $0.0782^{* * *}$ & $0.0651^{* * *}$ & $0.0620^{* * *}$ & $0.0650^{* * *}$ \\
\hline Assessment $_{t}$ & $(14.20)$ & $(9.90)$ & $(8.80)$ & (11.94) & $(7.84)$ & $(5.47)$ \\
\hline Neighborhood & $0.0417^{* * *}$ & $0.0465 * * *$ & $0.0459^{* * *}$ & $0.0433^{* * *}$ & $0.0347^{* * *}$ & $0.0302^{* *}$ \\
\hline Assessment $_{t-1}$ & $(9.48)$ & $(5.70)$ & $(5.42)$ & $(5.54)$ & $(8.46)$ & $(2.39)$ \\
\hline Exemption & $\begin{array}{c}0.0078^{* * *} \\
(4.33) \\
\end{array}$ & $\begin{array}{c}0.00802^{* *} \\
(2.84) \\
\end{array}$ & $\begin{array}{c}0.0086^{* *} \\
(2.45) \\
\end{array}$ & $\begin{array}{c}0.0079^{* *} \\
(2.45) \\
\end{array}$ & $\begin{array}{c}0.00378 \\
(0080) \\
\end{array}$ & $\begin{array}{c}0.0030 \\
(0.32) \\
\end{array}$ \\
\hline $\begin{array}{c}\bar{\beta}_{T, 2-4}-\beta_{T, 5-8}= \\
0\end{array}$ & *** & *** & *** & *** & $* * *$ & $* * *$ \\
\hline $\begin{array}{c}\beta_{T, 5-8}-\beta_{T, 9-17}= \\
0\end{array}$ & *** & $* * *$ & *** & *** & $* * *$ & \\
\hline $\begin{array}{c}\beta_{T, 9-17}-\beta_{T,>17}= \\
0\end{array}$ & & & $* *$ & & & $*$ \\
\hline$\overline{\mathrm{N}}$ & 212,537 & $\overline{53,556}$ & $\overline{46,866}$ & $\overline{588,483}$ & 31,685 & 21,947 \\
\hline Year Dummies & Yes & Yes & Yes & Yes & Yes & Yes \\
\hline $\begin{array}{l}\text { Neighborhood } \\
\text { Dummies }\end{array}$ & Yes & Yes & Yes & Yes & Yes & Yes \\
\hline $\begin{array}{c}\text { Housing Unit } \\
\text { Characteristics }\end{array}$ & Yes & Yes & Yes & Yes & Yes & Yes \\
\hline
\end{tabular}

${ }^{1}$ Absolute value of the z-statistics are reported in parentheses with ${ }^{* * *}$ significant at a $1 \%$ level, $* *$ at a $5 \%$ level, and $*$ at a $10 \%$ level.

Notes: Data includes all years from 2002 to 2008 . There are 125 neighborhoods and 6-7 years depending on the outcome variable. The overall sample has 248,918 observations on 41,276 single family homes. All specifications cluster standard errors at the neighborhood-year level (125 unique groups). Threshold for assigning neighborhood as a "Assessment Year" is that $70 \%$ of parcels have changes in their assessment. Results are robust to other reasonable thresholds. 
Table 8: Impact of Neighborhood Assessment on Mobility ${ }^{1}$

\begin{tabular}{|c|c|c|c|c|c|c|c|}
\hline & (a) & (b) & (c) & (d) & $(\mathrm{e})$ & (f) & (g) \\
\hline \multicolumn{8}{|c|}{ Dependent Variable: Sold Two Years Ago $(\mathrm{k}=\mathrm{t}-2)$} \\
\hline $\begin{array}{c}\text { Neighborhood } \\
\text { Assessment } \\
\text { Exemption }\end{array}$ & $\begin{array}{c}0.0015 \\
(0.93)\end{array}$ & $\begin{array}{l}-0.001 \\
(0.68)\end{array}$ & $\begin{array}{c}0.0017 \\
(0.73)\end{array}$ & $\begin{array}{c}-0.0009 \\
(0.71)\end{array}$ & $\begin{array}{c}-0.0006 \\
(0.50)\end{array}$ & $\begin{array}{c}-0.00063 \\
(0.50) \\
-0.062^{* * *} \\
(16.57)\end{array}$ & $\begin{array}{c}-0.00067 \\
(0.42) \\
-0.060^{* * *} \\
(15.57)\end{array}$ \\
\hline \multicolumn{8}{|c|}{ Dependent Variable: Sold Last Year $(\mathrm{k}=\mathrm{t}-1)$} \\
\hline $\begin{array}{c}\text { Neighborhood } \\
\text { Assessment } \\
\text { Exemption }\end{array}$ & $\begin{array}{c}0.0047^{* *} \\
(1.97)\end{array}$ & $\begin{array}{c}0.0025 \\
(1.05)\end{array}$ & $\begin{array}{c}0.0052^{* *} \\
(2.83)\end{array}$ & $\begin{array}{c}0.003^{*} \\
(1.84)\end{array}$ & $\begin{array}{c}0.0035^{*} \\
(1.77)\end{array}$ & $\begin{array}{c}0.0035^{*} \\
(1.79) \\
-0.065^{* * *} \\
(21.06)\end{array}$ & $\begin{array}{c}0.0035^{*} \\
(1.64) \\
-0.063^{* * *} \\
(18.74)\end{array}$ \\
\hline \multicolumn{8}{|c|}{ Dependent Variable: Sold This Year $(\mathrm{k}=\mathrm{t})$} \\
\hline $\begin{array}{c}\text { Neighborhood } \\
\text { Assessment } \\
\text { Exemption }\end{array}$ & $\begin{array}{c}0.00027 \\
(0.09)\end{array}$ & $\begin{array}{c}-0.0036 \\
(1.19)\end{array}$ & $\begin{array}{c}0.0009 \\
(0.41)\end{array}$ & $\begin{array}{l}-0.003 \\
(1.36)\end{array}$ & $\begin{array}{c}-0.002 \\
(0.81)\end{array}$ & $\begin{array}{c}-0.002 \\
(0.84) \\
-0.034^{* * *} \\
(16.54) \\
\end{array}$ & $\begin{array}{c}-0.0021 \\
(0.83) \\
-0.031^{* * *} \\
(12.70) \\
\end{array}$ \\
\hline \multicolumn{8}{|c|}{ Dependent Variable: Sold Next Year $(\mathrm{k}=\mathrm{t}+1)$} \\
\hline $\begin{array}{c}\text { Neighborhood } \\
\text { Assessment } \\
\text { Exemption }\end{array}$ & $\begin{array}{l}0.003 \\
(0.89)\end{array}$ & $\begin{array}{c}0.00005 \\
(0.03)\end{array}$ & $\begin{array}{c}0.0034 \\
(1.17)\end{array}$ & $\begin{array}{c}0.0003 \\
(0.20)\end{array}$ & $\begin{array}{c}0.00124 \\
(0.78)\end{array}$ & $\begin{array}{c}0.0012 \\
(0.76) \\
-0.018^{* * *} \\
(9.59)\end{array}$ & $\begin{array}{c}0.0012 \\
(0.66) \\
-0.016^{* * *} \\
(7.61) \\
\end{array}$ \\
\hline Year Dummies & No & Yes & No & Yes & Yes & Yes & Yes \\
\hline $\begin{array}{l}\text { Neighborhood } \\
\text { Dummies }\end{array}$ & No & No & Yes & Yes & Yes & Yes & Yes \\
\hline $\begin{array}{l}\text { Neighborhood } \\
\text { Trend }\end{array}$ & No & No & No & No & Yes & Yes & Yes \\
\hline $\begin{array}{c}\text { Housing } \\
\text { Characteristics }\end{array}$ & No & No & No & No & No & No & Yes \\
\hline
\end{tabular}

${ }^{1}$ Absolute value of the -statistics are reported in parentheses with ${ }^{* * *}$ significant at a $1 \%$ level, ${ }^{* *}$ at a $5 \%$ level, and ${ }^{*}$ at a $10 \%$ level. Notes: Data includes all years from 2002 to 2008. There are 125 neighborhoods and 6-7 years depending on the outcome variable. The overall sample has 248,918 observations on 41,276 single family homes. All specification cluster standard errors at the neighborhood- year level (125 unique groups). Threshold for assigning neighborhood as a Assessment Year is that $70 \%$ of parcels have changes in their assessment. Results are robust to other reasonable thresholds. 
Table 9: Impact of Neighborhood Assessment on Mobility, Panel Estimates ${ }^{1}$

(a)

(b)

(c)

(d)

(e)

\begin{tabular}{|c|c|c|c|c|c|}
\hline \multicolumn{6}{|c|}{ Dependent Variable: Sold Last Year $(\mathrm{k}=\mathrm{t}-1)$ : } \\
\hline \multicolumn{6}{|c|}{ Fixed Effect Estimates } \\
\hline & (a) & (b) & (c) & (d) & (e) \\
\hline $\begin{array}{l}\text { Neighborhood } \\
\text { Assessment }\end{array}$ & $\begin{array}{c}0.0070^{* * * *} \\
(3.88)\end{array}$ & $\begin{array}{c}0.0071^{* * * *} \\
(3.90)\end{array}$ & $\begin{array}{l}0.0016 \\
(1.23)\end{array}$ & $\begin{array}{c}-0.00002 \\
(0.02)\end{array}$ & $\begin{array}{c}0.00568^{* * *} \\
(3.69)\end{array}$ \\
\hline $\begin{array}{c}\text { Sold } 2 \text { Years } \\
\text { Ago }\end{array}$ & & $\begin{array}{c}-0.195^{* * *} \\
(73.53)\end{array}$ & & $\begin{array}{c}0.309^{* * *} \\
(120.70)\end{array}$ & \\
\hline & & & $\begin{array}{c}-0.0265^{* * *} \\
(39.80)\end{array}$ & $\begin{array}{c}-0.347^{* * *} \\
(39.10)\end{array}$ & $\begin{array}{c}-0.0786^{* * *} \\
(53.46)\end{array}$ \\
\hline Tenure $^{2}$ & & & & & $\begin{array}{c}0.00197^{* * * *} \\
(34.69) \\
\end{array}$ \\
\hline \multicolumn{6}{|c|}{ Dependent Variable: Sold Last Year $(\mathrm{k}=\mathrm{t}-1)$} \\
\hline \multicolumn{6}{|c|}{ Random Effect Estimates } \\
\hline $\begin{array}{l}\text { Neighborhood } \\
\text { Assessment }\end{array}$ & $\begin{array}{c}0.0050^{* * * *} \\
(3.13)\end{array}$ & $\begin{array}{c}0.00368^{* *} \\
(2.11)\end{array}$ & $\begin{array}{c}0.0039^{* *} \\
(2.76)\end{array}$ & $\begin{array}{c}0.0035^{* *} \\
(2.23)\end{array}$ & $\begin{array}{c}0.0054^{* * * *} \\
(3.72)\end{array}$ \\
\hline $\begin{array}{c}\text { Sold } 2 \text { Years } \\
\text { Ago }\end{array}$ & & $\begin{array}{c}-0.0115^{* * *} \\
(4.02)\end{array}$ & & $\begin{array}{c}-0.113^{* * *} \\
(32.68)\end{array}$ & \\
\hline & & & $\begin{array}{c}-0.0107^{* * * *} \\
(33.64)\end{array}$ & $\begin{array}{c}-0.0102^{* * *} \\
(31.59)\end{array}$ & $\begin{array}{c}-0.0455^{* * *} \\
(59.36)\end{array}$ \\
\hline Tenure $^{2}$ & & & & & $\begin{array}{c}0.0011^{* * * *} \\
(44.92)\end{array}$ \\
\hline
\end{tabular}

Dependent Variable: Sold Last Year $(\mathrm{k}=\mathrm{t}-1)$

Arellano-Bond Estimates

\begin{tabular}{c|c|c|c}
\hline Neighborhood & $0.0063^{* * *}$ & $0.0030^{* *}$ & \\
Assessment & $(4.56)$ & $(2.16)$ & \\
Sold 2 Years & $-0.0114^{* * *}$ & $-0.0217^{* * *}$ & $(7.80)$ \\
Ago & $(4.30)$ & $-0.0082^{* * *}$ & \\
Tenure & & $(8.86)$ & \\
\hline \hline
\end{tabular}

${ }^{1}$ Absolute value of the z-statistics are reported in parentheses with ${ }^{* * *}$ significant at a $1 \%$ level, ${ }^{* *}$ at a $5 \%$ level, and ${ }^{*}$ at a $10 \%$ level. Notes: Data includes all years from 2002 to 2008. There are 125 neighborhoods and 6-7 years depending on the outcome variable. The overall sample has 248,918 observations on 41,276 single family homes. All specifications cluster standard errors at the neighborhood-year level (125 unique groups). Threshold for assigning neighborhood as a year as a Assessment Year is that $70 \%$ of parcels have changes in their assessment. Results are robust to other reasonable thresholds. 
Table 10: Summary Statistics: Housing Characteristics

\begin{tabular}{|c|c|}
\hline Variable & Mean $/ \%$ \\
\hline Square Feet, Residence & $\begin{array}{l}1650.4 \\
(665.6)\end{array}$ \\
\hline Year Built & $\begin{array}{l}1968.7 \\
(16.96)\end{array}$ \\
\hline Square Feet, Lot & $\begin{array}{c}11,697.8 \\
(13,673.1)\end{array}$ \\
\hline Exterior Wall, Brick (\%) & 59.6 \\
\hline Exterior Wall, Mason (\%) & 24.7 \\
\hline Exterior Wall, Aluminum (\%) & 9.1 \\
\hline Exterior Wall, Other (\%) & 6.6 \\
\hline Basement, Full (\%) & 44.4 \\
\hline Basement, None (\%) & 46.2 \\
\hline Basement, Other (\%) & 9.4 \\
\hline Garage, Attached (\%) & 35.8 \\
\hline Garage, Detached (\%) & 24.0 \\
\hline Garage, Missing (\%) & 24.8 \\
\hline Garage, Basement (\%) & 15.4 \\
\hline Rooms, Total (\#) & $\begin{array}{c}2.76 \\
(3.51)\end{array}$ \\
\hline Bedrooms (\#) & $\begin{array}{c}0.05 \\
(0.440\end{array}$ \\
\hline Full bath $(\#)$ & $\begin{array}{c}1.65 \\
(0.68)\end{array}$ \\
\hline Half bath (\#) & $\begin{array}{c}0.42 \\
(0.52)\end{array}$ \\
\hline No Attic (\%) & 0.96 \\
\hline Heat, Hot air (\%) & 80.8 \\
\hline Heat, Missing & 19.0 \\
\hline Central Air & 87.1 \\
\hline Fixtures, Total (\#) & $\begin{array}{c}8.27 \\
(2.87) \\
\end{array}$ \\
\hline Fireplace, Masonry (\#) & $\begin{array}{c}0.58 \\
(0.73)\end{array}$ \\
\hline Fireplace, Prefrabicated (\#) & $\begin{array}{c}0.20 \\
(0.40)\end{array}$ \\
\hline Fuel, Gas (\%) & 64.2 \\
\hline Fuel, Electric (\%) & 16.8 \\
\hline Split Level (\%) & 11.6 \\
\hline
\end{tabular}

Data includes all years from 2002 to 2008 . The overall sample has 248,918 observations on 41,276 single family homes. All specications cluster standard errors at the neighborhood- year level (125 unique groups). 